\title{
Abundance of Lutzomyia longipalpis (Diptera: Psychodidae: Phlebotominae) and urban transmission of visceral leishmaniasis in Campo Grande, state of Mato Grosso do Sul, Brazil
}

\author{
Alessandra Gutierrez de Oliveira, Eunice Aparecida Bianchi Galati*, Orcy de Oliveira, \\ Gilliard Rezende de Oliveira, Italo Alexander Cabello Espindola, \\ Maria Elizabeth Cavalheiros Dorval, Reginaldo Peçanha Brazil**/+
}

\author{
Laboratório de Parasitologia, Universidade Federal de Mato Grosso do Sul, Campo Grande, MS, Brasil *Departamento de \\ Epidemiologia, Faculdade de Saúde Pública, USP, São Paulo, SP, Brasil **Departamento de Bioquímica e Biologia Molecular, \\ Instituto Oswaldo Cruz-Fiocruz, Av. Brasil 4365, 21045-900 Rio de Janeiro, RJ Brasil
}

The outspread and urbanization of visceral leishmaniasis (VL) in Campo Grande, state of Mato Grosso do Sul, lead us to undertake the present study over diversity and abundance of sand flies in the urban area to compare with previous search carried out during 1999/2000, before the identification of the disease in the human population.The captures were carried out with automatic light traps, weekly, from February 2004 to February 2005 on three sites including a forested area (Zé Pereira), two peridomicilies (shelters of domestic animals and cultivation areas), and intradomicilie. In the present study 110 collections were obtained during 13 months for $1320 \mathrm{~h}$ of collections, resulting in 5004 specimens, 3649 males and 1355 females belonging to the 20 following species: Brumptomyia avellari, Brumptomyia $s p$., Bichromomyia flaviscutellata, Evandromyia lenti, E. termitophila, E. cortelezzii, E. borrouli, Lutzomyia sp., L. longipalpis, Micropygomyia quinquefer, N. antunesi, N. whitmani, Pintomyia christenseni, Pi. damascenoi, Psathyromyia aragaoi, Ps. campograndensis, Ps. hermanlenti, Ps. shannoni, Pychodopygus claustrei, and Sciopemyia sordellii. L. longipalpis was the most abundant species in the anthropic environment with $92.22 \%$ of the captures. This shows an increase of sixty times in the density of L. longipalpis compared to the last sand fly evaluation in 1999/2000. The high density of L. longipalpis in Campo Grande is the main factor of risk in transmission of the disease to human in the urban area. The capture of N. antunesi, typical specie from Amazonian region, in Mato Grosso do Sul is reported for the first time.

Key words: Phlebotominae - Lutzomyia longipalpis - visceral leishmaniasis - Mato Grosso do Sul - Brazil

Leishmaniases are currently one of the biggest problems of public health in the state of Mato Grosso do Sul. Cutaneous leishmaniasis (CL) has been reported in practically all the cities of the state and visceral leishmaniasis (VL), since the decade of 1980 has shown to be highly endemic in the cities of Corumbá and Ladário (northwest of the state). The disease is now expanding for new areas of the state, also reaching the capital, Campo Grande, that registered the first canine autochthonous case in 2000 (Silva et al. 2000) and the first human case in 2002. In this year, 19 cases were diagnosed in the city, and during the years of 2003 and 2004, 100 and 126 cases had been notified, respectively, confirming the endemicity and expansion of the disease (Campo Grande 2006). The presence of the Lutzomyia longipalpis, main vector of $\mathrm{VL}$, in the city was evidenced by Oliveira et al. (2000) and from this finding, studies on the sand fly fauna were developed in the urban area

Financial support: Decit/Fundect, process 41/100208/2003, CNPq, Fiocruz

+Corresponding author: rpbrazil@ioc.fiocruz.br

Received 1 June 2006

Accepted 19 October 2006 and 28 species of sand fly were identified (Oliveira et al. 2003).

With the objective to compare the current abundance of $L$. longipalpis with the previous period of the beginning of the outbreak of VL in the urban area of Campo Grande, a longitudinal study of its sand fly fauna was carried out from February 2004 to February 2005.

\section{MATERIALS AND METHODS}

\section{Study area}

General characteristics - The city of Campo Grande, state of Mato Grosso Sul, Brazil, with $8.118,4 \mathrm{~km}^{2}$, is located geographically in the central of state, occupying $2.27 \%$ of its total area and, according to the Instituto Brasileiro de Geografia e Estatística with an urban population of 734,164 inhabitants in 2004 (Campo Grande 2005). The headquarters of the city are defined by the geographic coordinates $20^{\circ} 26^{\prime} 34^{\prime \prime}$ South latitude and $54^{\circ} 38^{\prime} 47^{\prime \prime}$ longitude West. The predominant climate of Campo Grande, according to the classification of Köppen, is of the rainy tropical type of Savannah, subtype $\mathrm{AW}$, characterized for bad annual distribution of rains, with occurrence defined of a dry period during the cold months of the year and a rainy period during the summer months. The annual average temperature is around $23^{\circ} \mathrm{C}$, December is the hottest month with approximately $25^{\circ} \mathrm{C}$, and the coldest is June, with $18^{\circ} \mathrm{C}$. 
Studied areas - The captures had been carried out in three points selected from previous work, where we observed a great density and diversity of sand flies (Oliveira et al. 2003): Mata do Zé Pereira, situated in the west region, an outskirt district created by a social program. It consist a part of a remaining forest rich in local fauna and flora; Chácara das Palmeiras, south region of the city, an area of 1 ha, with two houses, orchard with some species of trees fruit, kennel, goat pen, and a chicken house that make border with a residual forest of the neighboring land and Região Central (Taveirópolis district), a house with a chicken house in its yard.

Captures - In each selected fixed point, CDC-like light traps were set simultaneously in the interior of the bush (at ground level and tree canopy), in the edge of the bush (ground level) and man modified environment as: culture areas, chicken house, pigsty, kennel, goat pen, inside house, and balcony. The traps of the canopies had been installed approximately $5 \mathrm{~m}$ of height and the traps of the ground $1 \mathrm{~m}$. The collections had been weekly, from $6.00 \mathrm{pm}$ to $6.00 \mathrm{am}$, without obeying the summer schedules, in the period of February of 2004 to February of 2005. The captured specimens had been carried to the Laboratory of Parasitology of the Federal University of Mato Grosso of Sul for identification. The nomenclature of the adopted species was of Galati (2003).

The comparative analysis in relation to the density of $L$. longipalpis in the two studied years was gotten through the qui-square test $\left(\chi^{2}\right)$. For the evaluation of the most abundant species of sand flies, as well as its spacial distribution, the Index of Species Abundance (ISA) converted into a scale between zero and 1 was used, through the Standardised Index of Species Abundance (SISA). In this index, value 1 corresponds to the species most abundant (Roberts \& Hsi 1979). For the analysis of diversity and regularity of the species in the respective ecotopes were used the Shannon's Index (H), Pielou's (J), Buzas and Gibson's (E) (Hayek \& Buzas 1997).

\section{RESULTS}

In 110 captures carried through, during $1320 \mathrm{~h}$, a total of 5004 sand flies, 3649 males and 1355 females were collected. The sand fly species belong to four sub tribes, ten genera and 20 species: BRUMPTOMYIINA Brumptomyia avellari (Costa Lima, 1932), Brumptomyia sp, LUTZOMYIINA Evandromyia lenti (Mangabeira, 1938), Evandromyia termitophila (Martins, Falcão \& Silva, 1964), Evandromyia cortelezzii (Brèthes, 1923), Lutzomyia longipalpis (Lutz \& Neiva, 1912), Pintomyia christenseni (Young \& Duncan, 1994), Sciopemyia sordellii (Shannon \& Del Ponte, 1927), PSYCHODOPYGINA Nyssomyia antunesi (Coutinho, 1939), Nyssomyia whitmani (Antunes \& Coutinho, 1939), Psathyromyia aragaoi (Costa Lima, 1932), Psathyromyia campograndensis (Oliveira, Andrade Filho, Falcão \& Brazil, 2001) Psathyromyia hermanlenti (Martins, Silva \& Falcão, 1970), Psathyromyia shannoni (Dyar, 1929), Psychodopygus claustrei (Abonnenc, Léger \& Fauran, 1979) and SERGENTOMYIINA Micropygomyia quinquefer (Dyar, 1929).

Between February of 2004 and February of 2005, $L$. longipalpis was the species most frequent in the area studied, with $92.22 \%$ of captured specimens. This fact contrasts with the data obtained in the period of February of 1999 the February of 2000 where the species only represented $8.97 \%$ of the captured sand flies (Table V).

The difference in the captures of L. longipalpis in the three environments studied during the two investigated periods was statisticaly significant $(\mathrm{p}<$ 0.001) as demonstrated in Table I.

It is possible to observe also, in Table II, that the $L$. longipalpis passed from the 5th position in 1999/2000 to the first, becoming the most abundant species in the urban area of the city in the period of 2004/2005.

The total of sand flies captured weekly in the urban area of Campo Grande, the two studied periods (99/00 and $04 / 05)$ and the diversity Index $(\mathrm{H}, \mathrm{E}, \mathrm{J})$ is represented in Tables III and IV.

The diversity Index had been higher in the forested area than in the central area in both periods. The index of regularity $(\mathrm{J})$ in the central region $(0,0027)$ was significantly lesser in the second period in relation to the first one in the same area $(0,5156)$, demonstrating one strong dominance of one species, in the case of $L$. longipalpis.

\section{DISCUSSION}

The weekly collection with light traps in the same ecotopes of the city of Campo Grande, in the period of February of 2004 to February of 2005, confirmed the varieties of species in the urban environment as observed in the period of 1999/2000 (Oliveira et al. 2003).

In comparison of the two studied periods, considering the same months and ecotopes, it was observed that some previously species reported by Oliveira et al. (2003) such as Br. brumpti, Br. pintoi, $L$. cruzi, E. corumbaensis, E. teratodes, Ex. cerradincola, Mi. migonei, and Ps. punctigeniculata was not captured

TABLE I

Total number of Lutzomyia longipalpis captured in three environments of Campo Grande, state of Mato Grosso do Sul

\begin{tabular}{lcccr}
\hline & Mata do Zé Pereira & Região Central & Chácara das Palmeiras & Total \\
\hline Feb/1999-Feb/2000 & 0 & 54 & 17 & 71 \\
Feb/2004-Feb/2005 ${ }^{a}$ & 112 & 4385 & 118 & 4615 \\
\hline Total & 112 & 4439 & 135 & 4686 \\
\hline
\end{tabular}

$\chi^{2}: 115,75 ; \mathrm{p}<0.001 ; a$ : with a total of $1320 \mathrm{~h}$ of captures. 
TABLE II

Standardised Index of Species Abundance (SISA) of sand flies captured in Campo Grande, state of Mato Grosso do Sul

\begin{tabular}{|c|c|c|c|c|}
\hline Species & SISA & Position & SISA & Position \\
\hline Bumptomyia avellari & 0,41 & 5th & 0,27 & 15 th \\
\hline Psathyromyia hermanlenti & 0,29 & 8 th & 0,35 & 11th \\
\hline Psychodopygus claustrei & 0,31 & 7th & 0,32 & 12th \\
\hline Lutzomyia longipalpis & 1 & 1 st & 0,62 & 5th \\
\hline Ps. aragaoi & 0,27 & 9th & 0,54 & 7th \\
\hline Micropygomyia quinquefer & 0,22 & 10 th & 0,22 & 17th \\
\hline Pintomyia christenseni & 0,02 & 14th & 0,39 & 10th \\
\hline Nyssomyia antunesi & 0,22 & 9th & 0 & \\
\hline N. whitmani & 0,49 & 3rd & 0,13 & 19th \\
\hline Ps. shannoni & $\mathbf{0 , 4 5}$ & 4th & 0,51 & 8th \\
\hline Ps. campograndensis & 0,16 & 11th & 0,28 & 14th \\
\hline Brumptomyia sp. & 0,11 & 12th & 0,4 & 9th \\
\hline Evandromyia lenti & 0,4 & 6th & 0,76 & 2nd \\
\hline E. cortelezzii & 0,16 & 10th & 0,63 & 4 th \\
\hline Sciopemyia sordellii & 0,27 & 8th & 0,65 & 3rd \\
\hline P. damascenoi & 0,02 & 14th & 0,4 & 9 th \\
\hline Lutzomyia sp. & 0,02 & 14th & 0 & \\
\hline E. bourrouli & 0,02 & 14th & 0,16 & 18th \\
\hline E. termitophila & $\mathbf{0 , 5 8}$ & 2nd & 0,61 & 6th \\
\hline Bichromyia flaviscutellata & 0,08 & 13th & 0,22 & 17th \\
\hline Mcropygomyiai longipennis & $\mathbf{0}$ & & 0,95 & $1 \mathrm{st}$ \\
\hline E. teratodes & 0 & & 0,31 & 13th \\
\hline$B$. pintoi & 0 & & 0,04 & 22th \\
\hline E. corumbaensis & 0 & & 0,1 & 20th \\
\hline Migonemyia migonei & 0 & & 0,05 & $21 \mathrm{st}$ \\
\hline Expapillata cerradincola & 0 & & 0,05 & $21 \mathrm{sh}$ \\
\hline Ps. punctigeniculata & 0 & & 0,23 & 16th \\
\hline B. brumpti & 0 & & 0,05 & $21^{\text {st }}$ \\
\hline L. cruzi & 0 & & 0,05 & $21^{\mathrm{st}}$ \\
\hline
\end{tabular}

TABLE III

Number of sand flies captured in the urban areas of Campo Grande, state of Mato Grosso do Sul, in the period of $\mathrm{Feb} / 2004$ to Feb/2005

\begin{tabular}{|c|c|c|c|c|}
\hline Species & Mata do Zé Pereira & Região central & Chácara das Palmeiras & Total \\
\hline Brumptomyia avellari & 8 & 0 & 1 & 9 \\
\hline Psathyromyia hermanlenti & 55 & 0 & 0 & 55 \\
\hline Psychodopygus claustrei & 89 & 0 & 0 & 89 \\
\hline Lutzomyia longipalpis & 112 & 4385 & 118 & 4615 \\
\hline Ps.aragaoi & 36 & 0 & 0 & 36 \\
\hline Micropygomyia quinquefer & 10 & 0 & 0 & 10 \\
\hline Piintomyia christenseni & 1 & 0 & 0 & 1 \\
\hline Nyssomyia antunesi & 10 & 0 & 0 & 10 \\
\hline N. whitmani & 11 & 0 & 2 & 13 \\
\hline Ps. shannoni & 4 & 0 & 68 & 72 \\
\hline Ps. campograndensis & 6 & 0 & 0 & 6 \\
\hline Brumptomyia sp. & 3 & 0 & 0 & 3 \\
\hline Evandromyia lenti & 3 & 0 & 36 & 39 \\
\hline E.cortelezzii & 6 & 0 & 0 & 6 \\
\hline Sciopemyia sordellii & 1 & 0 & 3 & 4 \\
\hline P.damascenoi & 1 & 0 & 0 & 1 \\
\hline Lutzomyia sp. & 1 & 0 & 0 & 1 \\
\hline E. bourrouli & 1 & 0 & 0 & 1 \\
\hline E.termitophila & 0 & 1 & 30 & 31 \\
\hline Bichromyia flaviscutellata & 2 & 0 & 0 & 2 \\
\hline Total & 360 & 4386 & 258 & 5004 \\
\hline H: Shannon’s index & 1,9572 & 0,0019 & 1,2512 & 1 \\
\hline E: Buza \& Gibson's index & 0,3226 & 0,5009 & 0,4992 & 0,1359 \\
\hline J: Pielou's index & 0,6647 & 0,0027 & 0,6429 & 0,3338 \\
\hline
\end{tabular}


TABLE IV

Number of sand flies captured in the urban areas of Campo Grande, state of Mato Grosso do Sul, in the period of Feb/1999 to Feb/2000

\begin{tabular}{|c|c|c|c|c|}
\hline Species & Mata do Zé Pereira & Região Central & Chácara das Palmeiras & Total \\
\hline Brumptomyia avellari & 4 & 0 & 2 & 6 \\
\hline B. brumpti & 0 & 0 & 1 & 1 \\
\hline B. pintoi & 2 & 0 & 0 & 2 \\
\hline Brumptomyia sp. & 13 & 0 & 2 & 15 \\
\hline Psathyromyia hermanlenti & 44 & 0 & 1 & 45 \\
\hline Psychodopygus claustrei & 16 & 0 & 1 & 17 \\
\hline Lutzomyia longipalpis & 0 & 54 & 17 & 71 \\
\hline L. cruzi & 0 & 0 & 1 & 1 \\
\hline Ps.aragaoi & 51 & 0 & 3 & 54 \\
\hline Micropygomyia quinquefer & 9 & 0 & 0 & 9 \\
\hline M. longipennis & 103 & 0 & 1 & 104 \\
\hline Migonemyia migonei & 0 & 0 & 1 & 1 \\
\hline Pintomyia christenseni & 5 & 0 & 3 & 8 \\
\hline Nyssomyia whitmani & 3 & 0 & 1 & 4 \\
\hline Ps. shannoni & 8 & 0 & 52 & 60 \\
\hline Ps. campograndensis & 19 & 0 & 0 & 19 \\
\hline Expapillata cerradincola & 0 & 0 & 1 & 1 \\
\hline Evandromyia lenti & 5 & 1 & 102 & 108 \\
\hline E.cortelezzii & 4 & 3 & 3 & 10 \\
\hline E corumbaensis & 2 & 0 & 1 & 3 \\
\hline E.teratodes & 2 & 0 & 5 & 7 \\
\hline E.bourrouli & 5 & 0 & 0 & 5 \\
\hline E.termitophila & 0 & 1 & 172 & 173 \\
\hline Sciopemyia sordellii & 4 & 35 & 3 & 42 \\
\hline P. damascenoi & 13 & 0 & 2 & 15 \\
\hline Ps. punctigeniculata & 1 & 0 & 3 & 4 \\
\hline Bichromyia flaviscutellata & 5 & 0 & 1 & 6 \\
\hline Total & 318 & 94 & 379 & 791 \\
\hline H: Shannon's index & 2,2851 & 0,8921 & 1,607 & 2,5279 \\
\hline E: Buza \& Gibson's index & 0,4679 & 0,488 & 0,2168 & 0,4639 \\
\hline J: Pielou's index & 0,7505 & 0,5543 & 0,5156 & 0,7669 \\
\hline
\end{tabular}

in the present study, although the number of sand flies was approximately six times bigger. As related by Oliveira et al. (2003) the year of 1999 was atypical in Campo Grande with a period of drought, what certainly affected the density of sand flies at the time of captures.

$N$. whitmani appears as one of the most abundant species (SISA $=0,49)$, occupying the third position and was present, mainly, in areas next to forest (Table II). In other areas of the state, this species is also one of the most abundant (Galati et al. 1996, 2003, 2006) and was incriminated vetor of the CL in several regions of the country (Pessoa \& Coutinho 1941, Mayrink et al. 1979, Queiroz et al. 1994, Galati et al. 1996, Luz et al. 2000, Dias-Lima et al. 2003). Even so there is no report of authoctounous cases in the city of Campo Grande, the presence of $N$. whitmani is preoccupying, considering that $\mathrm{CL}$ is widely distributed in Mato Grosso Sul and also in neighboring municipalities of Campo Grande. This species is well adapted to the anthropic environment (Souza at al. 2001, Rangel \& Lainson 2003, Teodoro et al. 2003) being responsible for the periurban epidemiological pattern of the parasite transmission in several regions of Brazil.
In regard to Psy. claustrei, it was observed an increasing in the density when compared the two periods of study, however it was remained restricted to the forest. This species is typically from forest areas having been found naturally infected with parasites of the genus Leishmania (Ryan et al. 1987) in the region North of the country, but it is not considered, up to the moment, as vector of Leishmania.

$N$. antunesi, captured only in the forested areas of the Zé Pereira, is reported for the first time in Mato Grosso do Sul. This species is distributed widely through the Amazon region, having been found naturally infected by promastigotes in a endemic area of visceral leishmaniasis in the Island of Marajó, Pará (Ryan et al. 1984) and it was pointed also as a probable vector of Leishmania (Viannia) lindenbergi in Belém, Pará (Silveira et al. 2002). The presence of this species in this remaining path of forest in large distance from the Amazon region suggests the continue existence of vegetation in the past, probably destroyed by man action and further studies is necessary to correlates its presence related to the flora and fauna on the region. It is necessary to evaluate the potential of this species as Leishmania vector in the area, 
TABLE V

Comparative number of sand flies captured in the urban areas of Campo Grande, state of Mato Grosso do Sul in two periods (Feb/1999 to Feb/2000 and Feb/2004 to Feb/2005)

\begin{tabular}{|c|c|c|c|c|}
\hline \multirow[b]{2}{*}{ Species } & \multicolumn{2}{|c|}{$\mathrm{Feb} / 2004$ to $\mathrm{Feb} / 2005$} & \multicolumn{2}{|c|}{$\mathrm{Feb} / 1999$ to $\mathrm{Feb} / 2000$} \\
\hline & $\mathrm{N}$ & $\%$ & $\mathrm{n}$ & $\%$ \\
\hline Brumptomyia avellari & 9 & 0.18 & 6 & 0.75 \\
\hline Psathyromyia hermanlenti & 55 & 1.1 & 45 & 5.7 \\
\hline Psychodopygus claustrei & 89 & 1.77 & 17 & 2.15 \\
\hline Lutzomyia longipalpis & 4615 & 92.22 & 71 & 8.97 \\
\hline Ps. aragaoi & 36 & 0.72 & 54 & 6.82 \\
\hline Micropygomyia quinquefer & 10 & 0.2 & 9 & 1.13 \\
\hline Pintomyia christenseni & 1 & 0.02 & 8 & 1.01 \\
\hline Nyssomyia antunesi & 10 & 0.2 & 0 & 0 \\
\hline N.whitmani & 13 & 0.26 & 4 & 0.5 \\
\hline Ps.shannoni & 72 & 1.43 & 60 & 7.58 \\
\hline Ps.campograndensis & 6 & 0.12 & 19 & 2.4 \\
\hline Brumptomyia sp. & 3 & 0.06 & 15 & 1.9 \\
\hline Evandromyia lenti & 39 & 0.8 & 108 & 13.65 \\
\hline E.cortelezzii & 6 & 0.12 & 10 & 1.26 \\
\hline Sciopemyia sordellii & 4 & 0.08 & 42 & 5.31 \\
\hline P. damascenoi & 1 & 0.02 & 15 & 1.9 \\
\hline Lutzomyia sp. & 1 & 0.02 & 0 & 0 \\
\hline E.bourrouli & 1 & 0.02 & 5 & 0.63 \\
\hline E.termitophila & 31 & 0.62 & 173 & 21.87 \\
\hline Bichromyia flaviscutellata & 2 & 0.04 & 6 & 0.8 \\
\hline B. brumpti & 0 & 0 & 1 & 0.12 \\
\hline$B$. pintoi & 0 & 0 & 2 & 0.25 \\
\hline L. cruzi & 0 & 0 & 1 & 0.12 \\
\hline M.longipennis & 0 & 0 & 104 & 13.14 \\
\hline Migonemyia migonei & 0 & 0 & 1 & 0.12 \\
\hline Expapillata cerradincola & 0 & 0 & 1 & 0.12 \\
\hline E. corumbaensis & 0 & 0 & 3 & 0.4 \\
\hline E. teratodes & 0 & 0 & 7 & 0.9 \\
\hline Ps.punctigeniculata & 0 & 0 & 4 & 0.5 \\
\hline Total & 5004 & 100 & 791 & 100 \\
\hline
\end{tabular}

in view of the proximity of the houses near the forested area.

Bi. flaviscutellata again was captured in one areas (Mata do Zé Pereira) and, even so light trap is not the better method to capture this species, its presence in Campo Grande strengthens its dispersion in Mato Grosso Sul (Dorval et al. 2005, Galati et al. 2006). This species assumes importance in view of its involvement in the transmission of Le. (Le.) amazonensis, responsible for the diffuse form of CL in several region of Brazil, and more recently in Bela Vista, Mato Grosso do Sul (Dorval et al. 2006).

The presence of $L$. longipalpis in the city of Campo Grande six years ago (Oliveira et al. 2000) had taken the authors to point out an alert to the Health Authorities in order to prevent the establishment of visceral leishmaniasis in the human population, as observed in other regions of Brazil (Arias et al. 1996). Since our publication in 2000, L. longipalpis increased significantly $(\mathrm{p}<0.001)$ in its density, practically being captured with exclusiveness in the central areas of the city, what seems of epidemiological importance. In the subsequent years and until the present date more than $246 \mathrm{VL}$ human cases was reported and around $20 \%$ of dogs are seropositive for the disease with an alarming numbers of notifications, reaching children and adults, with early clinical manifestations and lethality index around 11\% (Campo Grande 2006) and the data presented in this paper shows the importance of the exposition of the human population to L. longipalpis, first factor of risk for the occurrence of the disease.

We believe that the Fundação Nacional de Saúde has the necessity of a reevaluation of all measures used on vector control, as the eco-epidemiology of visceral leishmaniasis in Brazil is more complex than we thought (Lainson \& Rangel 2005).

\section{ACKNOWLEDGEMENTS}

To Mr Floriano, Mrs Ilma, Mrs Íris, Mrs Isaura, Mr José, Mrs Elizabeth, and Mr Luís for their patience and kindness. To UCDB for logistic help during this work.

\section{REFERENCES}

Arias JR, Monteiro PS, Zicker F 1996. The re-emergence of visceral leishmaniasis in Brazil. Emerg Infect Di 2: 145-146.

Campo Grande 2005. Perfil Socioeconômico de Campo 
Grande. Prefeitura Municipal de Campo Grande, Instituto Municipal de Planejamento Urbano de Campo Grande, 258 pp.

Campo Grande 2006. Relatório de Notificações de LV, Prefeitura Municipal de Campo Grande, Secretaria de Saúde de Campo Grande, Serviço de Vigilância Epidemiológica.

Dias-Lima AG, Guedes MLS, Sherlock IA 2003. Horizontal stratification of the sandfly sauna (Diptera:Psychodidae) in a transitional vegetation between caatinga and tropical rain forest, state of Bahia, Brazil. Mem Inst Oswaldo Cruz 98: 733737.

Dorval MEC, Oshiro ET, Cristaldo G, Rocha HC, Peixoto TA, Alves MA, Oliveira AG, Galati EAB, Brazil RP, Cunha RV 2005. The sandfly fauna (Diptera: Psychodidae: Phlebotominae) of an area of cutaneous leishmaniasis in municipality of Bela Vista, Mato Grosso do Sul State, Brazil. Proceedings of ISOPS V, Arch Inst Pasteur Tunis 82: 107.

Dorval MEC, Oshiro ET, Cupollilo E, Camargo de Castro AC, Alves TP 2006. Ocorrência de leishmaniose tegumentar americana no Estado do Mato Grosso do Sul associada à infecção por Leishmania (Leishmania) amazonensis. Rev Soc Bras Med Trop 39: 43-46.

Galati EAB 2003. Classificação de Phlebotominae. In EF Rangel, R Lainson (eds), Flebotomíneos do Brasil, Fiocruz, Rio de Janeiro, p. 23-51.

Galati EAB, Nunes VL, Boggiani PC, Dorval MEC, Cristaldo G, Rocha HC, Oshiro ET, Damasceno-Júnior GA 2006. Phlebotomines (Diptera: Psychodidae) in forested areas of the Serra da Bodoquena, state of Mato Grosso do Sul, Brazil. Mem Inst Oswaldo Cruz 101: 175-193.

Galati EAB, Nunes VL, Cristaldo G, Rocha HC 2003. Aspectos do comportamento da fauna flebotomínea (Diptera: Psychodidae) em foco de leishmaniose visceral e tegumentar na Serra da Bodoquena e área adjacente, Estado de Mato Grosso do Sul, Brasil. Rev Pat Trop 32: 235-261.

Galati EAB, Nunes VL, Dorval MEC, Oshiro ET, Cristaldo G, Espíndola MA, Rocha HC, Garcia WB 1996. Estudo dos flebotomíneos (Diptera, Psychodidae) em área de leishmaniose tegumentar, no Estado de Mato Grosso do Sul, Brasil. Rev Saú Públ 30: 115-128.

Hayek LAC, Buzas MA 1997. Surveying Natural Populations, Columbia University Press, New York, p. 347-389.

Luz BE, Membrive N, Castro EA, Dereure J, Pratlong F, Dedet JA, Pandey A, Thomaz-Soccol V 2000. Lutzomyia whitmani (Diptera: Psychodidae) as a vector of Leishmania $(V$.) braziliensis in Paraná State, Douthern Brazil. Ann Trop Med Parasit 94: 623-631.

Lainson R, Rangel EF 2005. Lutzomyia longipalpis and the ecoepidemiology of American visceral leishmaniasis, with particular reference to Brazil - A Review. Mem Inst Oswaldo Cruz 100: 811-827.

Mayrink W, Williams P, Coelho MV, Dias M, Martins AV 1979.
Epidemiology of dermal leishmaniasis in the Rio Doce Valley, State of Minas Gerais, Brazil. Ann Trop Med Parasitol 73: 123-137.

Oliveira AG, Andrade Filho JD, Falcão AL, Brazil RP2003. Estudo de flebotomíneos (Diptera, Psychodidae, Phlebotominae) na zona urbana da cidade de Campo Grande, Mato Grosso do Sul, Brasil, 1999-2000. Cad. Saú Públ 19: 933-944.

Oliveira AG, Falcão AL, Brazil RP 2000. Primeiro encontro de Lutzomyia longipalpis (Lutz \& Neiva, 1912) na área urbana de Campo Grande, MS, Brasil. Rev Saú Públ 34: 654-655

Pessoa SB, Coutinho JO 1941. Infecção natural e experimental dos flebótomos pela Leishmania braziliensis no Estado de São Paulo. O Hospital 20: 25-35.

Queiroz RG, Vasconcelos IAB, Vasconcelos AW, Pessoa FAC, Sousa RN, David JR 1994. Cutaneous leishmaniasis in Ceará State in Northeastern Brazil: Incrimination of Lutzomyia whitmani (Diptera: Psychodidae) as a vector of Leishmania braziliensis in Baturité municipality. Am J Trop Med Hyg 50: 693-698.

Rangel EF, Lainson R 2003. Flebotomíneos do Brasil, Fundação Oswaldo Cruz, Rio de Janeiro, 368 pp.

Roberts DR, Hsi BP 1979. An index of species abundance for use with mosquito surveillance data. Environm Entomol 8: 1007-1013.

Ryan L, Lainson R, Shaw JJ 1987. Leishmaniasis in Brazil XXIV. Natural flagellate infections of sandfly (Diptera: Psychodidae) in Pará State, with particular reference to the role of Psychodopygus wellcomei as the vector of Leishmania (Leishmania) brasiliensis in the Serra dos Carajás. Trans $R$ Soc Trop Med Hyg 81: 353-359.

Ryan L, Silveira FT, Laison R, Shaw JJ 1984. Leishmanial infections in Lutzomyia longipalpis and Lu. antunesi (Diptera: Psychodidae) on the Island of Marajó, Pará State, Brazil. Trans R Soc Trop Med Hyg 78: 547-548.

Silva ES, De Carvalho FG, Silva EA, Fiozi E, Oliveira AG, Brazil RP 2000. Primeiro relato de leishmaniose visceral canina em área urbana do município de Campo Grande, Mato Grosso do Sul. Rev Soc Bras Med Trop 33: 318-319.

Silveira FT, Ishikawa EAY, De Souza AAA, Laison R 2002. An outbreak of cutaneous leishmaniasis among soldiers in Belém, Pará State, Brazil, caused by Leishmania (Viannia) lindenbergi $\mathrm{n}$. sp. A new leishmanial parasite of man in the Amazon Region. Parasite 9: 43-50.

Souza NA, Andrade-Coelho CA, Vilela ML, Rangel EF 2001. The Phlebotominae sandfly (Diptera: Psychodidae) fauna of two atlantic rain forest reserves in the state of Rio de Janeiro, Brazil. Mem Inst Oswaldo Cruz 96: 319-324.

Teodoro U, Alberton D, Kuhl JB, Santos ES, Santos DR, Santos AR, Oliveira O, Silveira GV, Valdrinez M, Lonardoni C 2003. Ecologia de Lutzomyia (Nyssomyia) whitmani em área urbana do município de Maringá, Paraná. Rev Saú Públ 37: 651-656 